\title{
Life Cycle of Gall Midge on Red Chilli in West Sumatra
}

\author{
Munzir Busniah \\ Plant Pest and Disease Department, Faculty of Agriculture, Andalas University, Padang, West Sumatra, Indonesia \\ E-mail: bmunzir@yahoo.co.id
}

\begin{abstract}
Study of the life cycle of the gall midge (Asphondylia capsici Barnes) (Diptera: Cecidomyiidae) has been performed in pepper (Capsicum annuum L.). The experiment was conducted in laboratory experiments carried out at the Laboratory of Plant Pest Disease, Faculty of Agriculture, University of Andalas Padang, from January to June 2012. The objective was to study the life cycle of the gall midge in pepper. Gall midge egg white, elongated round, length 0,69 and width $0,35 \mathrm{~mm}$. Early instar larvae rounded elongated, transparent color and a whitish or yellowish white. Instar larva up getting flattened by the color yellow to brownish yellow. The larvae live in the chilies. Pupa brown to blackish brown, $3.0 \mathrm{~mm}$ long and $2.3 \mathrm{~mm}$ wide, located in the chilies. Pradewasa stage lasted 22 days. Imago brown or blackish brown. Imago body length of males and females is almost the same, at $2.8 \mathrm{~mm}$, but the body of the female imago fatter than the males. Imago males live longer ( 35 hours) compared with female imago (32 hours). Imago female fecundity is 124 eggs. The life cycle of gall midge on pepper plants 25 days.
\end{abstract}

Keywords — Life cycle, gall midge, red chilli, West Sumatra

\section{INTRODUCTION}

Asphondylia capsici Barnes (Diptera: Cecidomyiidae) is one of the insect pests that attack the chilies and cause symptoms gall midge ([1], [3], [8], [2]. In Indonesia $A$. capsici was first reported attacked pepper plants in Java [3], and attacks in West Sumatra was first reported in 1993 [2]. Besides Indonesia, A. capsici also attacked pepper plants in various countries, India [13] in the Andaman Islands [10], and in Cyprus [9]. There has been no reports of harm caused A. capsici in Indonesia, but the level of attacks on pepper plants can reach 40 percent [1]. Thus this pest has the potential to cause harm, but so far there has been no way to control that can be done. Therefore, to provide the basis of good control it is necessary to study on the life cycle of this pest. For it has done research that aims to understand the life cycle of the gall midge.

\section{MATERIALS AND MethodS}

The experiment was conducted in Pauh Padang District of West Sumatra, house wire and laboratory of Plant Pests and Diseases Department of the Faculty of Agriculture, University of Andalas Padang, from January to June 2012. Chili cultivation is done in accordance with the treatment of local farmers. Gall midge infestations occur naturally. Observations on various parameters relating to the biology of $A$. capsici made since peppers flowering plants. When flowers bloom chili characterized by the label. It is assumed that the eggs are laid when flowers bloom.
Eggs. Observation of morphology (shape, size, and color) eggs is done by picking chilies of plot were then taken to the laboratory to be maintained. Maintenance is carried out in a ventilated plastic box as the stricken fruit per box. Maintenance is done until the imago A. capsici from the chilies. Imago that appear in pairs were reared on pepper plants and were placed in the insect cage. After one day the female imago turned off. The female imago dissected under a stereo binocular microscope to observe the shape, size, and color of the eggs. Measurements were repeated 10 times.

Larvae and pupae. Larvae and pupae morphological observation and long development done by picking 10 pieces of chili stricken from experimental plots each day that begins the day after the flowers bloom until the imago $A$. capsici stricken out of the fruit. The fruit was brought to the laboratory for observation. In the laboratory, fruits dissected and observed by binocular stereo microscope its morphology (shape, size and color as well as the changes that occur in the larvae and pupae).

To determine larval and pupal development time, selected 10 pieces labeled chili that show symptoms. Fruit is observed every day until the imago A. capsici out of the fruit with a pit exit signs are lagging imago or pupa casings on the infected fruit. Long live immature backdated interest began to blossom out imago assuming that at the time of blooming flowers occur egg infestation by imago $A$. capsici.

Imago. Observations on morphology imago include males and females, long life, and the fecundity (number of eggs produced by a female). Imago males and females were 
obtained from infected fruit derived from experimental plots, observed under a binocular microscope to determine its morphology. For a long observation of life and fecundity, it takes 10 pairs of adults of $A$. capsici obtained from infected fruit in the field. Each pair of newly emerged imago put into a cage containing flowering pepper plants that had been prepared earlier. Imago allowed to lay eggs on the imago chilies until death. Long live imago determined from appearing to death. A female fecundity was calculated from the amount of chilies showing symptoms coupled with the remaining eggs in the ovaries. The number of eggs remaining in the ovaries calculated by dissecting ovaries dead imago conducted under binocular microscope.

Life cycle. Based on the information collected about the egg, larva, pupa and imago, where life and signs that can be observed about the symptoms that occur then made a diagram of the life cycle $A$. capsici.

\section{RESULTS AND DISCUSSION}

Eggs. The eggs of $A$. capsici is white, round length $(0,69$ $\pm 18.25 \mathrm{~mm}$ length, $0,36 \pm 7.79 \mathrm{~mm}$ width) (Fig. 1) and (Table 1). Kozhukhov [6] stated that the eggs of A. capsici colorless when placed and then turned into darker when mature, which become yellow or reddish yellow when it will hatch. The eggs of $A$. capsici are greater, are 1,45 x $170 \mathrm{~mm}$ [9].

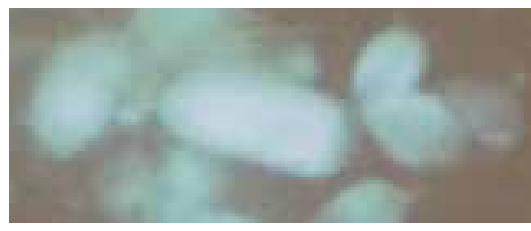

Fig. 1. The eggs of A. capsici.

Larvae. External structure of larval A. capsici was reduced and only the mouth parts are well developed and visible with highly contrasting colors compared to other parts of the body (Fig. 2). In the body there are nine spiracles, the spiracles are on protoraks and eight abdominal spiracles there. Orphanides [9] also found the same thing.

TABLE I

The Size Of Eggs, Larvae, Prapupae, Pupae And Imago, Wing Span AND LONG ANTENNAE OF MALE AND FEMALE A. CAPSICI.

\begin{tabular}{|l|l|l|l|l|}
\hline \multicolumn{1}{|c|}{ Observation } & $\mathrm{N}$ & $\begin{array}{c}\text { Min. } \\
\mathrm{mm}\end{array}$ & $\begin{array}{c}\text { Max. } \\
\mathrm{mm}\end{array}$ & $\begin{array}{c}\text { Mean } \\
\mathrm{mm}\end{array}$ \\
\hline Egg & & & & \\
\hline Egg length & 10 & 50,8 & 87,3 & $69 \pm 18,3$ \\
\hline Egg width & 10 & 27,7 & 43,3 & $35,5 \pm 7,8$ \\
\hline Larvae & & & & \\
\hline Early instar length & 10 & 0,7 & 1,0 & $0,87 \pm 0,1$ \\
\hline Early instar width & 10 & 0,2 & 0,3 & $0,25 \pm 0,1$ \\
\hline Late instar length & 10 & 2,5 & 3,1 & $2,77 \pm 0,2$ \\
\hline Late instar width & 10 & 1,4 & 1,6 & $1,52 \pm 0,1$ \\
\hline Prapupae and Pupae & & & & \\
\hline Prapupae length & 10 & 2,6 & 3,1 & $2,81 \pm 0,2$ \\
\hline Prapupae width & 10 & 1,4 & 1,6 & $1,49 \pm 0,1$ \\
\hline Pupae length & 10 & 2,5 & 3,4 & $3,03 \pm 0,4$ \\
\hline Pupae width & 10 & 1,0 & 1,1 & $2,27 \pm 3,1$ \\
\hline Imago & & & & \\
\hline Female length & 10 & 2,7 & 3,1 & $2,88 \pm 0,1$ \\
\hline Fem. thoracic width & 10 & 0,9 & 1,2 & $1,08 \pm 0,1$ \\
\hline
\end{tabular}

\begin{tabular}{|l|l|l|l|l|}
\hline Fem. wing span & 10 & 7,2 & 8,2 & $7,77 \pm 0,3$ \\
\hline Fem. antenna length & 10 & 1,4 & 1,8 & $1,65 \pm 0,1$ \\
\hline Male length & 10 & 2,6 & 3,1 & $2,84 \pm 0,2$ \\
\hline Male thoracic width & 10 & 0,8 & 1,1 & $0,92 \pm 0,1$ \\
\hline Male wing span & 10 & 6,8 & 7,8 & $7,10 \pm 0,3$ \\
\hline Male antenna length & 10 & 1,8 & 2,3 & $1,99 \pm 0,2$ \\
\hline
\end{tabular}

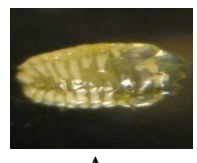

A

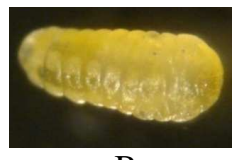

B

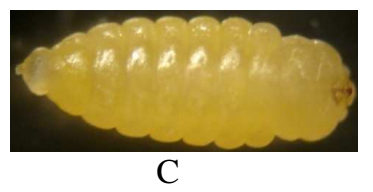

Fig. 2. (A) Larvae instar 1, (B) instar 2, dan (C) instar 3 A. Capsici.

During the larval development of $A$. capsici there are three larval body size. This indicates that the larvae of $A$. capsici consists of three instars (Fig. 2). Kozhukhov [6] and Orphanides [9] stated that the larvae of A. capsici consists of three instars. In general, early instar larvae-colored transparent and certain parts of the abdomen visible white, cylindrical shaped with the anterior larger than the posterior part. In a further development towards instar larvae of $A$. capsici into yellow, into flattened, the dorsal to be concave and ventral convect.

Early instar larvae transparent colorless to light yellow and certain parts on most of the abdomen is white. Thoracic portion is greater than the parts of the body (Fig. 2). Kozhukhov [6], Orphanides [9], and Research Machines plc [11] states that early instar larvae are white or transparent. Further larval yellow to yellowish color and there are still a small part of the body is transparent. Thoracic part also tend to be larger than the other parts of the body (Fig. 2). Further instar larvae are yellow. Abdomen wider than thorax (Fig. 2). Kozhukhov [6] stated that the length of the larval instar up to $4 \mathrm{~mm}$.

Prapupae and Pupae. Prapupae A. capsici is yellow like the color of advanced instar larvae. Length $2.81 \pm 0.19 \mathrm{~mm}$ prapupa, and width $1.49 \pm 0.09 \mathrm{~mm}$ (Table 2). The size is almost the same as the advanced instar larvae.

The newly formed pupa brownish yellow or orange and the eyes, legs, antennae and wings much darker than the other parts, and then will be transformed into dark brown (Fig. 4). The length of the pupae is $3.03 \pm 0.37 \mathrm{~mm}$ and a width is $2.27 \pm 3.11 \mathrm{~mm}$ (Table 1). Kozhukhov [6] stated that the length equal to the length of the pupal instar further, which is about $4 \mathrm{~mm}$, and pupae are also usually the same color with the color of the larvae but darker.

Development time immature A. capsici in chili fruit is quite diverse, ie 19-28 days (mean 22.3 days) (Table 2). The diversity of the larval stage of $A$. capsici probably due to differences in the size of infected fruit. Size of chilies that infected by $A$. capsici chilies are much smaller compared with the healthy fruit, and a decrease in the size of the fruit is very diverse. Marchosky and Craig [7] states that the long life Asphondylia atriplicis (Diptera: Cecidomyiidae) on Atriplex cenescens influenced by the size of the swelling and larvae in the swelling depth, the deeper presence in the fruit of A. atriplicis long life tend to be longer. Supartha [12] stated that the longer the development of insect larvae of the same type can vary that it is determined by various factors, such as host plant, and environmental conditions. 
Imago. Imago A. capsici (Fig. 3) and a brownish-black body is covered by fine hairs. Morphologically there are three things that distinguish females with a male imago, ie body size, long antennae and ovipositor existence. The body length is almost the same as the female and the males. Female body length is $2.88 \pm 0.11 \mathrm{~mm}$ and $2.84 \pm 0.20 \mathrm{~mm}$ for the male. But the female much fatter than the male. Female body width is $1.08 \pm 0.11 \mathrm{~mm}$ while the males only $0.92 \pm 0.10 \mathrm{~mm}$. Obesity happens because the abdomen containing eggs. Kozhukhov [6] stated that A. capsici body length is about $3 \mathrm{~mm}$ ( 0.3 inches). Male antenna is much longer than the female antenna, which is $1.99 \pm 0.18 \mathrm{~mm}$ in the males and only $1.65 \pm 0.13 \mathrm{~mm}$ in females. Orphanides [9] states that the antenna A. capsici is one very striking differentiating between females with male imago. Imago female has a straight ovipositor and strong coming out of the tip of the abdomen. Kozhukhov [6] states that the female imago avopositor $A$. capsici has a strong and hard.

Longevity of the female almost is the same as the male. The longevity of the females is longer, is $32 \pm 17.7$ hours, and the males is 12.2 hours \pm 35 (Table 2). Orphanides [9] get a longer time, the imago A. capsici long life is 26-97 hours (mean 55 hours).

TABLE II

The DeVElopments Of IMMATURE, AND IMAgo A. CAPSICI.

\begin{tabular}{|l|c|c|c|c|}
\hline \multicolumn{1}{|c|}{ Parameter } & n & Min. & Max. & Mean \\
\hline Immature development (days) & 10 & 19 & 28 & 22,3 \\
\hline Females live (hours) & 10 & 13 & 72 & $32 \pm 17,7$ \\
\hline Males live (hours) & 10 & 21 & 48 & $35 \pm 12,2$ \\
\hline Fecundity (eggs) & 10 & 105 & 148 & $124 \pm 13,3$ \\
\hline
\end{tabular}

The fecundity of $A$. capsici is $124 \pm 13.36$ eggs (Table 2). Orphanides [9] stated that female can lay 42 eggs. Freeman and Geoghagen [4] states that the fecundity of Asphondylia boerhaaviae was $98.8 \pm 11.2$ eggs per female.

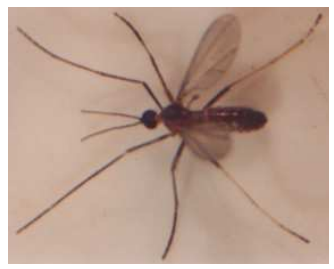

Fig. 3. The female A. capsici that emerging from the infected chilies.

Life History. In the infected chilies, the larvae only was found one although there are also two larvae were found, but very rarely happen. Slightly different results proposed by Orphanides [9], which is in the infected chilies A. capsici are the larvae, but also found two even three larvae. A. capsici larvae live in the space at the chilli flesh attacked and there is a clear boundary between the living space of larvae with fruit flesh (Fig. 4). Imai and Ohsaki [5] stated that the boundary between the living space of larvae with fruit flesh consists of a network of like-kallus. Kozhukhov [6] states that such network-kallus is a result of the plant's response to the presence of larvae as well as due to the chemical compounds produced by the activity of the larvae.

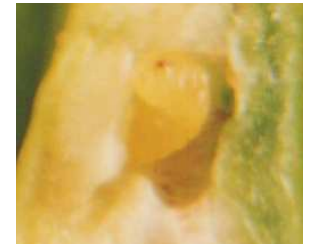

A

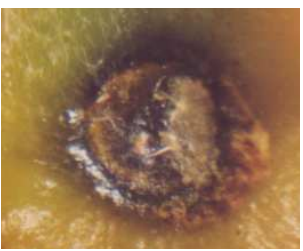

C

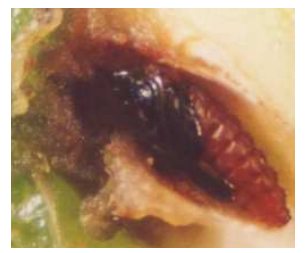

B

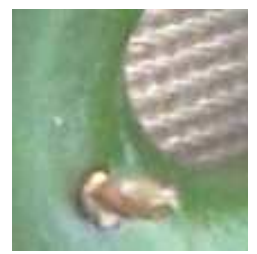

$\mathrm{D}$
Fig. 4 (A) Larvae A. capsici in chili fruit, (B) anterior part of the pupae which leads to the skin chilies, (C) the chilies skin necrosis at the time of the imago will come out, and (D) the eksuvie left in the skin chilies.

Prapupae of A. capsici remain in the space of developing larvae in the fruit. Pupae (Fig. 4) still takes place in the space of developing larvae in the fruit. Orphanides [9] stated that $A$. capsici pupae formed and remain in the previously niche rather loud is also a place to live larvae.

The anterior pupae toward the skin fruit (Fig. 4) and the fruit skin adjacent to the anterior pupal will be necrosis (Fig. 4). This is a preparation to exit the imago and the imago does not need energy to penetrate the skin. With its own strengths imago A. capsici out into eksuvie pupa and chilies skin tissue that has died. Usually eksuvie pupa will be left on the skin (Fig. 4). Orphanides [9] states that the adult has emerged it will leave eksuvie pupa protruding portion of the fruit affected.

Eggs, larvae and pupae of A. capsici live in the chilies and imago free life. The life cycle of $A$. capsici in chilies 19-28 days (mean 22.3 days) (Table 1 and Fig. 5). Freeman and Geoghagen [4] stated that in one year there are 17 times the life cycle of Asphondylia boerhaviae on Boerhavia diffusa, or the life cycle of $A$. boerhaviae was 21.47 days. Differences long life cycle of $A$. capsici may be influenced by the size of the swelling fruit. Marchosky and Craig [7] states that Asphondylia atriplicis Townsend (Diptera: Cecidomyiidae) on Atriplex canescens (Pursh) Nutall (Chenopodiaceae) increases survival when swollen size bigger because the larvae live in the greater swelling.

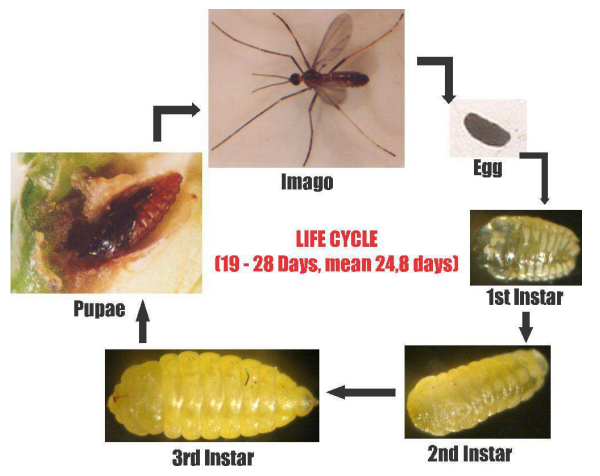

Fig. 5. The life cycle of A. capsici in chili. 


\section{CONCLUSIONS}

Gall midge egg white, elongated round, length 0,69 and width $0,35 \mathrm{~mm}$. Early instar larvae rounded elongated, transparent color and a whitish or yellowish white. Instar larva up getting flattened by the color yellow to brownish yellow. The larvae live in the chilies. Pupa brown to blackish brown, $3.0 \mathrm{~mm}$ long and $2.3 \mathrm{~mm}$ wide, located in the chilies. Pradewasa stage lasted 22 days. Imago brown or blackish brown. Imago body length of males and females is almost the same, at $2.8 \mathrm{~mm}$, but the body of the female imago fatter than the males. Imago males live longer ( 35 hours) compared with female imago (32 hours). Imago female fecundity is 124 eggs. The life cycle of gall midge on pepper plants 25 days.

\section{REFERENCES}

[1] Anastasia, D. dan Maryana, N. 2005. Chili pod gall midge, Asphondylia sp. (Diptera: Cecidomyiidae) a new pest of chili (Capsicum annuum) in Bogor. Program \& Abstract the first International Conference of Crop Security 2005. Brawijaya University, Malang Indonesia September 20th - 22th, 2005.

[2] $\mathrm{CAB}$ International. 1993. Identification Diptera: Cecidomyiidae. International Institute of Entomology. An Institute Of CAB International Identification Service Report. 56 Queen's Gate. London, SW7 5JR, UK.

[3] Franssen, C. J. H., Nijveldt, W., dan Mo, T. T. 1953. Een voor Spaanse peper schadelijke galmug. Biomedical and Life Sciences. European Journal of Plant Pathology. Volume 59, Number 5 (178-180) September, 1953. Springer Netherlands
[4] Freeman, B.E. and Geoghagen, A. 1989. A Population Study in Jamaica on the Gall Midge, Asphondylia boerhaaviaea; a Contribution to Spatial Dynamics. J. Animal Ecology. 58 (1) : 367 - 382.

[5] Imai, K. dan Ohsaki, N. 2004. Oviposition site of and gall formation by the fruit gall midge Asphondylia aucubae (Diptera: Cecidomyiidae) in relation to internal fruit structure. Entomological Science 7 (2), $133-137$.

[6] Kuzukhov. 2007. http://encarta.msn.com (C) 1997-2007 Microsoft Corporation. All Rights Reserved

[7] Marchosky Jr, R. J., dan Craig, T. P. 2004. Gall Size-Dependent Survival for Asphondylia atriplicis (Diptera: Cecidomyiidae) on Atriplex canescens. Environmental Entomology Article: pp. 709-719

[8] Maryana, N., Anastasia, D. dan Prima, R. 2006. Asphondylia sp. (Diptera: Cecidomyiidae) Infesting Chili Pods in Bogor, West Java, Indonesia. 6th International Congress of Dipterology. 23-28 September 2006. Fukuoka, JAPAN

[9] Orphanides, G.M. 1975. Biology of the Carob Midge Complex, Asphondylia spp (Diptera: Cecidomyiidae) in Cyprus. Bull. Ent. Res. $65: 381-390$.

[10] Prasad, G. S. Ranganath, H. R. 2001. Occurrence of chilli gall midge, Asphondylia capsici Barnes (Cecidomyiidae: Diptera) in south Andamans, Andaman Islands. Journal- Bombay Natural History Society. J.C. Daniel for Bombay Natural History Society. ISSN 00066982 India. 2001, Vol 98; PART 3, pages 468

[11] Research Machines plc. 2007. All rights reserved. Helicon Publishing is a division of Research Machines plc. www.DermaTechRx.com.

[12] Supartha, I. W. 1988. Bionomi Liriomyza Huidobrensis (Blanchard) (Diptera: Agromizidae) Pada Tanaman Kentang (Disertasi). Institut Pertanian Bogor.

[13] Tomar, R. K. S., Yadav, H. S., Agrawal, R. K. 1997. Parasitoids of Chilli Gall Midge, Asphondylia capsici and Their Role in Chilli Ecosystem. Indian journal of entomology (Indian j. entomol.) ISSN 0367-8288 Coden Ijena8. 1997, vol. 59, nº 2 , pp. 173-178 